\title{
Kinetic Properties and Structural Gharacterization of Highly Purified Acetyl-CoA Synthetase from Bovine Heart and Tissue Distribution of the Enzyme in Rat Tissues
}

\author{
Momoyo Ishikawa, Takahiro Fujino*, Hitoshi \\ Sakashita, Kosuke Morikawa and Tokuo Yamamoto* \\ Protein Engineering Research Institute, Suita, Osaka 565, \\ and *Tohoku University Gene Research Center, Sendai 981
}

\begin{abstract}
Ishikawa, M., Fujino, T., Sakashita, H., Morikawa, K. and Yamamoto, T. Kinetic Properties and Structural Characterization of Highly Purified Acetyl-CoA Synthetase from Bovine Heart and Tissue Distribution of the Enzyme in Rat Tissues. Tohoku J. Exp. Med., 1995, 175 (1), 55-67_-Acetyl-CoA synthetase from bovine heart has been purified to homogeneity and been crystallized. The purification procedure involves ammonium sulfate precipitation and subsequent column chromatography on DEAE-Sepharose, Blue-Sepharose, CoA-Agarose and Superose 6 . The purified enzyme has a specific activity of 45 units/mg protein, and its molecular weight estimated by sodium dodecyl sulfate polyacrylamide gel electrophoresis is approximately 72,000. The purified enzyme specifically utilizes acetate, ATP and CoA. Apparent $K m$ values of the purified enzyme for acetate, $\mathrm{CoA}$, and ATP were $0.16 \mathrm{mM}, 0.14 \mathrm{mM}$ and $0.25 \mathrm{mM}$, respectively. Limited digestion with trypsin, subtilisin BPN' and chymotrypsin revealed that the enzyme contains a $56 \mathrm{k}$ segment resistant to these proteases. Secondary structure contents of the purified enzyme and the $56 \mathrm{k}$ tryptic fragment were analyzed by circular dichroism measurement. The intact molecule contains $30 \% \quad \alpha$-helix and $30 \%$ $\beta$-structure, and trypsin digests $\alpha$-helix rich regions more substantially. Western blot analysis of rat tissue homogenates by specific antibodies against the purified enzyme indicated that the $72 \mathrm{k}$ enzyme is present in a wide variety of tissues and is most abundant in heart and kidney. - acetyl-CoA synthetase; bovine heart; crystallization; purification; tissue distribution
\end{abstract}

Acetyl-CoA synthetase (EC 6.2.1.1) catalyses the formation of acetyl-CoA from acetate, ATP and CoA. Although acetyl-CoA, the final product of this enzyme, is an important intermediate in various metabolic pathways including fatty acid biosynthesis, cholesterol biosynthesis and citric acid cycle, the physiological role of this enzyme is still unknown. Acetyl-CoA synthetase is a member of the firefly luciferase superfamily (Toh 1990, 1991). This enzyme family includes acetyl-CoA synthetases from Aspergillus nidulans and Neurospora crassa

Received August 15, 1994; revision accepted for publication October 22, 1994. 
(Connerton et al. 1990), mammalian long-chain acyl-CoA synthetases (Suzuki et al. 1990; Abe et al. 1992; Fujino and Yamamoto 1992), luciferases from fireflies (De Wet et al. 1987; Masuda et al. 1989) and click beetle (Wood et al. 1989), Bacillus brevis gramicidin S synthetase 1 (Hori et al. 1989; Kräzschmar et al. 1989), B. brevis tyrocidine synthetase 1 (Weckermann et al. 1988), Penicillium chrysogenum $\delta$-(L- $\alpha$-aminoadipyl)-L-cysteinyl-D-valine synthetase (Smith et al. 1990; Díez et al. 1990) and 4-coumarate: CoA ligases from parsley (Lozoya et al. 1988; Zhao et al. 1990). All enzymes belonging to this enzyme family catalyze two step reactions: adenylation of substrates and the subsequent thioester formation. They were found to contain a conservative sequence motif, Ser-Gly-(small hydrophilic residue) ${ }_{2}$-Gly-(any residue)-Pro-Lys-Gly (Toh 1990).

Although acetyl-CoA synthetase was purified from bovine heart mitochondria (Webster 1965), its primary, secondary and tertiary structures have not been revealed. As an initial approach to elucidate the structure of this enzyme by cDNA cloning and $x$-ray crystallography, we have highly purified acetyl-CoA synthetase from bovine heart. In this paper, we describe kinetic properties and a secondary structure content of the highly purified enzyme. We also describe the tissue distribution of the enzyme in rat tissues.

\section{Materials and Methods}

\section{Materials}

CoA (Grade 1), malate dehydrogenase and citrate synthase were purchased from Boehringer Mannheim GmbH (Mannheim, Germany). Trypsin and chymotrypsin from Sigma Chemical Company (St. Louis, MO, USA). Sephadex G-25, DEAE-Sepharose (CL-6B), Blue-Sepharose (CL-6B), CoA Agarose (Type 5), Superose 6 (HR 10/30) and molecular weight marker for electrophoresis were obtained from Pharmacia LKB Biotechnology (Uppsala, Sweden). The reagents for protein assay and prestained high and low range molecular weight markers were purchased from Bio-Rad Laboratories (Hercules, CA, USA). Bovine serum albumin fraction $\mathrm{V}$ was purchased from Pierce Chemical Company (Rockford, IL, USA). NADH, NAD ${ }^{+}, \mathrm{ATP}, \mathrm{PMSF}$ and all other reagents were obtained from Wako Pure Chemicals (Kyoto). Horse anti-mouse IgG $(\mathrm{H}+\mathrm{L})$ coupled to alkaline phosphatase and alkaline phosphatase substrate kit were from Vector Laboratories Inc. (Burlingame, CA, USA).

\section{Enzyme purification}

A typical purification is described. All procedures were carried out at 0 to $4^{\circ} \mathrm{C}$.

Step 1. Ammonium sulfate precipitation. About $2 \mathrm{~kg}$ of ground bovine hearts was homogenized with 1.1 volumes of $50 \mathrm{mM}$ Tris- $\mathrm{HCl}$ buffer, $\mathrm{pH} 8.0$ containing $80 \mathrm{mM} \mathrm{KCl}, 1 \mathrm{mM} \mathrm{DTT}$ and $0.1 \mathrm{mM}$ PMSF. The homogenate was centrifuged to remove cell debris $(600 \times g$ for $10 \mathrm{~min})$, and the supernatant was 
subjected to ammonium sulfate precipitation. Solid ammonium sulfate of $243 \mathrm{~g}$ was slowly added to 1-liter of the supernatant to achieve $40 \%$ saturation. This mixture was centrifuged at $16,000 \times g$ for $20 \mathrm{~min}$. Solid ammonium sulfate of 97 $\mathrm{g}$ was again added to the $16,000 \times g$ supernatant to achieve $55 \%$ saturation. After centrifugation $(16,000 \times g$ for $20 \mathrm{~min})$, the ammonium sulfate precipitate was resuspended in $10 \mathrm{ml}$ of buffer $\mathrm{A}(50 \mathrm{mM}$ Tris-HCl, $\mathrm{pH} 8.0$ and $1 \mathrm{mM} \mathrm{DTT})$ and applied on to a Sephadex G-25 column $(5 \times 43 \mathrm{~cm})$, previously equilibrated with buffer A. The column was eluted with buffer A at a flow rate of $120 \mathrm{ml} / \mathrm{hr}$. Fractions exhibiting enzyme activities were collected.

Step 2. DEAE-Sepharose chromatography. The fractions containing acetylCoA synthetase activities from the Sephadex G-25 chromatography were pooled and loaded onto a DEAE-Sepharose column $(5 \times 30 \mathrm{~cm})$ equilibrated with buffer A. The column was washed with three column volumes of buffer A and eluted with a liner concentration gradient made between three column volumes of buffer A and the same volume of buffer A containing $1 \mathrm{M} \mathrm{KCl}$ at a flow rate of $140 \mathrm{ml} /$ hr. Fractions exhibiting enzyme activities were collected. To concentrate the enzyme solution pooled from the DEAE-Sepharose chromatography step, solid ammonium sulfate was added to achieve $60 \%$ saturation. The resulting precipitate was collected by centrifugation at $16,000 \times g$ for $10 \mathrm{~min}$, dissolved in $10 \mathrm{ml}$ of buffer $\mathrm{A}$ and dialyzed against buffer $\mathrm{A}$.

Step 3. Blue-Sepharose CL-6B chromatography. The dialyzed enzyme solution was applied onto a Blue-Sepharose column $(2.5 \times 20 \mathrm{~cm})$ equilibrated with buffer A. The column was washed with five column volumes of buffer A and eluted with a linear concentration gradient made between three column volumes of buffer $\mathrm{A}$ and the same volume of buffer $\mathrm{A}$ containing $1 \mathrm{M} \mathrm{KCl}$; the flow rate was $35 \mathrm{ml} / \mathrm{hr}$ and $8 \mathrm{ml}$ fractions were collected. Fractions exhibiting enzyme activities were pooled and concentrated by ammonium sulfate precipitation.

Step 4. CoA agarose chromatography. The enzyme solution from the BlueSepharose chromatography step was dialyzed against buffer A and then loaded onto a CoA agarose column $(1.3 \times 10 \mathrm{~cm})$ equilibrated with buffer $\mathrm{A}$. The column was washed with five column volumes of buffer $\mathrm{A}$ and eluted with a linear concentration gradient established between 2.5 column volumes of buffer $\mathrm{A}$ and the same volume of buffer A containing $1 \mathrm{M} \mathrm{KCl}$; the flow rate was $4.5 \mathrm{ml} / \mathrm{hr}$ and $1 \mathrm{ml}$ fractions were collected. The fractions exhibiting enzyme activities were combined.

Step 5. Superose 6 chromatography. The enzyme solution from the CoA agarose chromatography step was concentrated by a Centricon-30 micro concentrator (Amicon, Inc., Beverly, MA, USA) and loaded onto a Superose 6 column (25-ml bed volume) using FPLC system (Pharmacia). The column was equilibrated and eluted with buffer A containing $1 \mathrm{M} \mathrm{KCl}$; the flow rate was $0.5 \mathrm{ml} / \mathrm{min}$ and $1 \mathrm{ml}$ fractions were collected.

The results of a typical purification of acetyl-CoA synthetase from bovine 
heart were summarized in Table 1 . The purified enzyme could be stored at $4^{\circ} \mathrm{C}$ for at least two weeks. When glycerol was added to the enzyme solution at a final concentration of $20 \%(\mathrm{w} / \mathrm{v})$, it could be stored at $4^{\circ} \mathrm{C}$ for 1 month; more than $85 \%$ of the full activity was preserved.

\section{Assay of acetyl-CoA synthetase activity}

The activity of acetyl-CoA synthetase was measured by the spectrophotometric assay (Hele 1954; Pearson 1965). In this assay, the rate of acetylCoA formation was determined by coupling the reaction of acetyl-CoA synthetase with those of malate dehydrogenase and citrate synthase and following the production of $\mathrm{NADH}$. The standard reaction mixture (total volume, $1 \mathrm{ml}$ ) contained $100 \mathrm{mM}$ Tris- $\mathrm{HCl}$ buffer $\left(\mathrm{pH} \mathrm{8.5)}, 10 \mathrm{mM} \mathrm{MgCl}_{2}, 10 \mathrm{mM}\right.$ potassium acetate, $8 \mathrm{mM}$ L-malate , $6 \mathrm{mM}$ ATP, $2.5 \mathrm{mM}$ DTT, $2 \mathrm{mM}$ CoA, $1 \mathrm{mM} \mathrm{NAD}{ }^{+}, 0.1$ $\mathrm{mM}$ NADH, $3 \mathrm{U}$ of malate dehydrogenase and $30 \mathrm{U}$ of citrate synthase. The production of $\mathrm{NADH}$ was followed either at $24^{\circ} \mathrm{C}$ or $37^{\circ} \mathrm{C}$ with a recording photometer (Hitachi U-2000, Tokyo) at wavelength $340 \mathrm{~nm}$. All assays were carried out within a range where the reaction proceeded linearly with time and the initial rate of reaction was proportional to the amount of enzyme added. One unit (U) of enzymatic activity is defined as the amount which catalyzes the formation of $1 \mu \mathrm{mol}$ of $\mathrm{NADH}$ per minute under the standard condition. This procedure for the assay is essentially the same as that reported previously (Londesborough et al. 1973).

\section{Proteolytic analysis}

The purified enzyme was partially digested with trypsin, subtilisin BPN' and chymotrypsin in $50 \mathrm{mM}$ Tris- $\mathrm{HCl}, \mathrm{pH} 8.0$ and $1 \mathrm{mM}$ DTT at $20^{\circ} \mathrm{C}$ for various incubation time: the final concentration of the purified enzyme and these proteases

TABLE 1. Purification of acetyl-CoA synthetase from bovine heart

\begin{tabular}{lccccc}
\hline \multicolumn{1}{c}{ Step } & $\begin{array}{c}\text { Protein } \\
(\mathrm{mg})\end{array}$ & $\begin{array}{c}\text { Total } \\
\text { activity } \\
(\mathrm{U})\end{array}$ & $\begin{array}{c}\text { Specific } \\
\text { activity } \\
(\mathrm{U} / \mathrm{mg})\end{array}$ & $\begin{array}{c}\text { Yield } \\
(\%)\end{array}$ & $\begin{array}{c}\text { Purifica- } \\
\text { tion fold }\end{array}$ \\
\hline Crude extract & 39,000 & - & - & - & - \\
Ammonium sulfate & 3,830 & 751 & 0.2 & 100 & 1 \\
precipitation & & & & & \\
DEAE-sepharose & 256 & 240 & 0.9 & 32 & 5 \\
Blue-sepharose & 13.7 & 147 & 11.0 & 19 & 55 \\
CoA agarose & 2.7 & 55.2 & 20.3 & 7 & 102 \\
Superose 6 & 0.5 & 15.3 & 30.6 & 2 & 153 \\
\hline
\end{tabular}

Two kg of bovine heart was used. Enzymatic activity was measured at $24^{\circ} \mathrm{C}$ by the spectrophotometric method with the standard reaction mixture. For experimental details, see "Materials and Methods". 
were $1 \mathrm{mg} / \mathrm{ml}$ and $5 \mu \mathrm{g} / \mathrm{ml}$, respectively. Reactions were stopped by boiling for 2 min in a loading buffer and the reaction products were analyzed by SDSpolyacrylamide gel electrophoresis.

\section{Circular dichroism measurement}

The CD spectra of the purified enzyme and the tryptic fragments were measured on a J-600 automatic spectropolarimeter (Japan Spectroscopic Co., Ltd., Tokyo) over the range of 200-250 nm using a cell with an optical path of $2 \mathrm{~mm}$. Trypsin digestion of the purified enzyme was carried out as described above and the reaction was stopped at an appropriate time by the addition of diisopropyl fluorophosphate at a final concentration of $0.036 \mathrm{mg} / \mathrm{ml}$. Proteins were prepared as $0.2 \mathrm{mg} / \mathrm{ml}$ solution in $10 \mathrm{mM}$ Tris- $\mathrm{HCl}$ buffer, $\mathrm{pH} 8.0$.

\section{Crystallization}

To crystallize the enzyme, the purified enzyme was concentrated to 5-20 mg/ $\mathrm{ml}$ using a Centricon-30 micro concentrator. The crystallization was performed using the hanging drop method (Ollis and White 1990). A $10 \mu$ l drop of a solution containing $6 \mathrm{mg} / \mathrm{ml}$ of the purified enzyme in $50 \mathrm{mM}$ Tris- $\mathrm{HCl}(\mathrm{pH} \mathrm{8.0})$, $1 \mathrm{mM}$ DTT, $2 \mathrm{mM}$ CoA and $4 \mathrm{mM} \mathrm{ADP}$ was placed on a cover slip and vapordiffused at $20^{\circ} \mathrm{C}$ with $1 \mathrm{ml}$ of $100 \mathrm{mM}$ Tris-HCl, $\mathrm{pH} 8.0$, containing $10 \%$ 2-methyl2, 4-pentanediol.

\section{Immunochemical procedures}

Mouse antisera to acetyl-CoA synthetase were prepared using the purified enzyme. Initially, $50 \mu \mathrm{g}$ of the purified enzyme emulsified with complete Freund's adjuvant was injected to a mouse subcutaneously. Subsequently two intraperitoneal injections with $10 \mu \mathrm{g}$ of the antigen with the adjuvant were given at 6 -week intervals. The immunoglobulin fraction was isolated by ammonium sulfate precipitation. Control immunoglobulin was similarly obtained from a nonimmunized rabbit.

\section{Western blot analysis}

Male Wister strain rats weighing $200-300 \mathrm{~g}$ were used for the Western blot analysis of the enzyme in various tissues. Rat tissues were placed in 9 volumes of cold $10 \mathrm{mM}$ Tris- $\mathrm{HCl}$ buffer ( $\mathrm{pH}$. 7.5) containing $0.25 \mathrm{M}$ sucrose and homogenized using a Polytron homogenizer (Kinematica Co., Switzerland) at a maximum speed for $1 \mathrm{~min}$. The homogenates were then centrifuged at $1,000 \times g$ for $10 \mathrm{~min}$ to remove cell debris and the supernatants were used for the Western blot analysis. The tissue homogenates diluted $1: 1$ with $2 \times$ SDS sample buffer $(60 \mathrm{mM}$ Tris-HCl, pH 7.5, 2 mM EDTA $10 \mathrm{mM}$ 2-mercaptoethanol, 20\% glycerol, and 2\% SDS) were loaded on each lane of a $10 \%$ SDS-polyacrylamide gel, separated by electrophoresis, and electrophoretically transferred onto a nitrocellulose membrane (Sam- 
brook et al. 1989). The Western blots were probed with antibodies against bovine heart acetyl-CoA synthetase and control antibodies from a nonimmunized mouse. Second antibodies were horse anti-mouse IgG $(\mathrm{H}+\mathrm{L})$ coupled to alkaline phosphatase. The immunoreactive bands were visualized using 5-bromo-4-chloro-3indolyl phosphate/nitro blue tetrazolium as described previously (Sambrook et al. 1989).

\section{Other methods}

SDS-polyacrylamide gel electrophoresis was carried out as described by Laemmli (1970). Protein was determined by the method of Bradford (1976), using a Bio-Rad protein assay kit. Amino acid composition was determined by the method of Spackman et al. (1958) with an amino acid analyzer (SYSTEM $6300 \mathrm{E}$, Beckman Instruments, Inc., Fullerton, CA, USA); samples (200-220 $\mu \mathrm{g}$ ) were hydrolyzed with $6 \mathrm{M} \mathrm{HCl}$ under vacuum at $150^{\circ} \mathrm{C}$ for $1 \mathrm{hr}$.

\section{Results and Discussion}

Purification of the enzyme. Acetyl-CoA synthetase from bovine heart was purified to homogeneity as evidenced by SDS polyacrylamide gel electrophoresis (Fig. 1). The purification procedure involves precipitation of crude extracts with ammonium sulfate and chromatography on DEAE-Sepharose, Blue-Sepharose CoA Agarose and Superose 6 ("Materials and Methods" and Table 1). The overall purification starting from the crude extracts was 153 -fold with a yield of $2 \%$. The purified enzyme exhibited specific activities of $30 \mathrm{units} / \mathrm{mg}$ protein at $24^{\circ} \mathrm{C}$

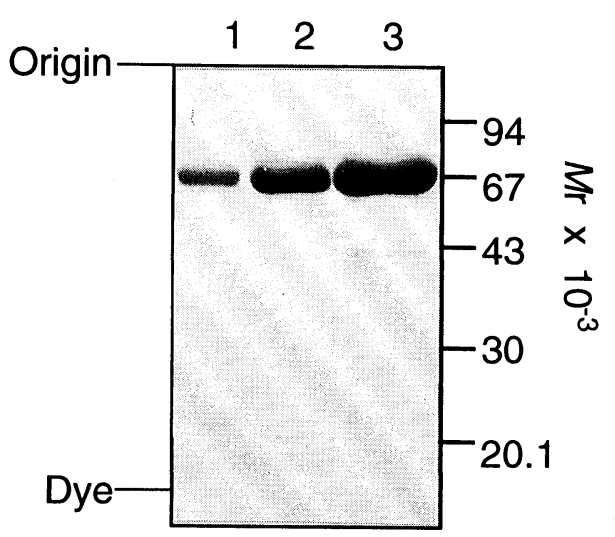

Fig. 1. SDS-polyacrylamide gel electrophoresis of acetyl-CoA synthetase from bovine heart. Two micrograms (lane 1), $4 \mu \mathrm{g}$ (lane 2) and $8 \mu \mathrm{g}$ (lane 3 ) of the purified acetyl-CoA synthetase were electrophoresed on a $10 \%$ SDSpolyacrylamide gel and stained with Coomassie brilliant blue R250. The marker proteins used were soybean trypsin inhibitor $(M r 20,100)$ carbonic anhydrase $(\boldsymbol{M r} 30,000)$, ovalbumin ( $M r 43,000)$, bovine serum albumin ( $M r$ $67,000)$, phosphorylase b $(M r 94,000)$. 
and 45 units $/ \mathrm{mg}$ protein at $37^{\circ} \mathrm{C}$; this value is the highest value as far as we know. The purified enzyme absolutely requires acetate, ATP and CoA for its activity. When citrate synthase and malate dehydrogenase were omitted from the reaction mixture, no reduction of $\mathrm{NAD}^{+}$occurred, indicating that acetyl-CoA is a reaction product. The molecular weight of the enzyme estimated by SDS-polyacrylamide gel electrophoresis was approximately 72,000. This value is consistent with the molecular weight estimated from the sedimentation velocity by Londesborough et al. (1973). Table 2 compares the amino acid composition of the purified enzyme with those obtained from the amino acid sequences of the cloned acetyl-CoA synthetases from $A$. nidulans and $N$. crassa (Connerton et al. 1990), revealing a close resemblance. Furthermore, these sequences evaluate 73,000 and 69,000 molecular weights for the two acetyl-CoA synthetases, respectively, which are

TABLE 2. Comparison of the amino acid composition of acetyl-CoA synthetase from bovine heart with those of acetyl-CoA synthetases from $A$. nidulans and $N$. crassa

\begin{tabular}{lcccr}
\hline & \multicolumn{2}{c}{ Bovine heart } & & \\
\cline { 2 - 3 } Amino acid & $\begin{array}{c}\text { This work } \\
(\text { mol \%) }\end{array}$ & $\begin{array}{c}\text { Londesborough } \\
(\text { mol \%) }\end{array}$ & $\begin{array}{c}\text { A. nidulans } \\
(\text { mol \% })\end{array}$ & $\begin{array}{c}\text { N. crassa } \\
(\text { mol \%) }\end{array}$ \\
\hline Ala & 9.2 & 8.6 & 8.2 & 8.8 \\
Cys & - & 1.6 & 0.7 & 0.8 \\
Asp/Asn & 8.4 & 8.6 & $6.4 / 2.1$ & $5.4 / 2.2$ \\
Glu/Gln & 7.3 & 9.0 & $6.9 / 1.5$ & $5.9 / 2.2$ \\
Phe & 3.5 & 3.3 & 3.7 & 2.9 \\
Gly & 9.2 & 9.4 & 8.5 & 8.1 \\
His & 2.7 & 2.4 & 3.3 & 3.0 \\
Ile & 5.6 & 4.5 & 6.0 & 5.6 \\
Lys & 5.9 & 4.9 & 6.3 & 5.0 \\
Leu & 10.7 & 9.0 & 6.6 & 6.9 \\
Met & 1.8 & 1.9 & 1.3 & 1.9 \\
Pro & 5.2 & 5.3 & 5.5 & 5.8 \\
Arg & 5.8 & 4.9 & 5.4 & 6.0 \\
Ser & 5.7 & 6.1 & 6.0 & 6.9 \\
Thr & 5.9 & 6.7 & 5.8 & 6.6 \\
Val & 9.2 & 8.2 & 9.9 & 9.7 \\
Trp & - & 1.7 & 2.1 & 2.2 \\
Tyr & 4.0 & 4.1 & 3.9 & 4.0 \\
\hline
\end{tabular}

Duplicate analyses were made as described in "Materials and Methods", and the mean values are given. No corrections have been made for losses during hydrolysis or for incomplete hydrolysis. Half cystine and tryptophan were not determined.

a,b The amino acid compositions were deduced from cDNA sequences (Connerton et al. 1990). ' Condesborough et al. (1973). 
essentially close to that of the same enzyme from bovine hearts. These results suggest that the mammalian enzyme has a similar amino acid sequence to those of the fungi.

Kinetic properties of the purified enzyme. Studies were made on the substrate specificity and kinetic properties of the purified enzyme. As shown in Table 3, the enzyme specifically utilized acetate; although the enzyme was able to activate propionate, acrylate, butyrate, and valerate, the relative activities for these compounds were less than $1.5 \%$ of that for acetate. The apparent $K m$ values, as estimated by Lineweaver-Burk plots, were $0.16 \mathrm{mM}$ for acetate, $0.14 \mathrm{mM}$ for CoA, and $0.25 \mathrm{mM}$ for ATP. These values are comparable to those reported by Webster (1965). The effect of $\mathrm{pH}$ on the activity of the enzyme was determined by varying the $\mathrm{pH}$ with Tris- $\mathrm{HCl}$ buffers ( $\mathrm{pH} 7.5-9.0)$, and the enzyme exhibited a $\mathrm{pH}$ optimum at 8.5.

Limited proteolysis and $C D$ spectral variations of the enzyme. To analyze the domain structure of the enzyme, we carried out limited proteolysis of the purified enzyme using trypsin, subtilisin BPN', and chymotrypsin (Fig. 2). The treatment of the purified enzyme with these proteases, including a low specific subtilisin BPN', produced a common $56 \mathrm{k}$ fragment, although the enzymatic activity was lost by these proteolytic digestions. This result suggests that the enzyme contains a $56 \mathrm{k}$ core region that is highly resistant to these proteases.

To analyze the secondary structure content of the enzyme, we measured CD spectral variations of the purified enzyme and the $56 \mathrm{k}$ proteolytic fragment generated by trypsin digestion. The $72 \mathrm{k}$ purified enzyme was found to consist of approximately $30 \% \quad \alpha$-helix and $30 \% \quad \beta$-structure (Fig. 3). Digestion of the purified enzyme with trypsin decreased $\alpha$-helix content by $10 \%$, suggesting that the enzyme contains an $\alpha$-helix rich structure susceptible to trypsin digestion.

Crystallization of the enzyme. With the aim of x-ray structural determination, we attempted to crystallize the purified enzyme. We first tried to crystallize

TABLE 3. Substrate specificity of the purified acetyl-CoA synthetase from bovine heart

\begin{tabular}{lc}
\hline Substrate & Relative activity $(\%)$ \\
\hline Acetate & 100 \\
Propionate & $<1.5$ \\
Acrylate & $<1.5$ \\
Butyrate & $<1.0$ \\
Valerate & $<1.0$ \\
\hline
\end{tabular}

Enzyme activity was assayed at $37^{\circ} \mathrm{C}$ by the spectrophotomeric method with the standard reaction mixture, except that CoA concentration was increased to $100 \mathrm{mM}$. Values are expressed as relative activity to acetate $(100 \%$ value; $40 \mathrm{U} / \mathrm{min}$ per $\mathrm{mg}$ protein). 

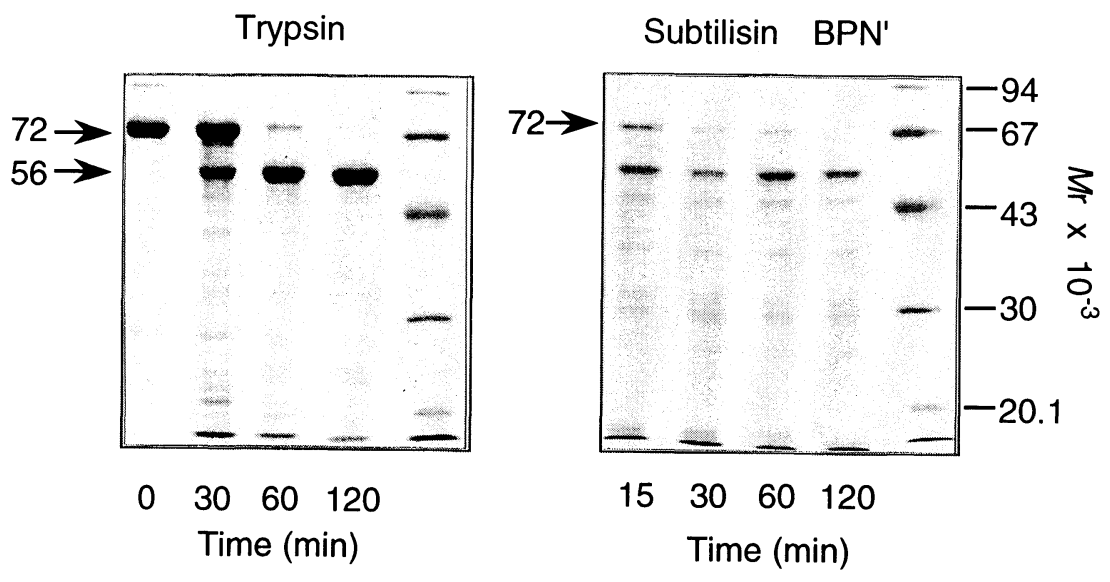

\section{Chymotrypsin}

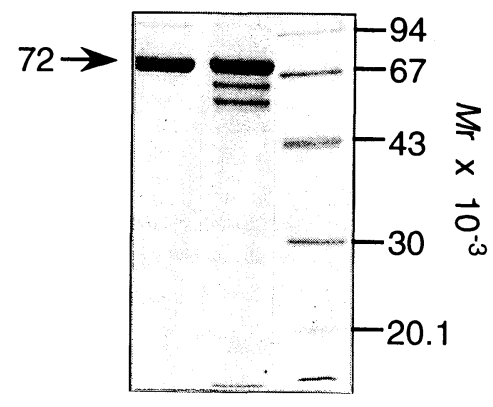

$0 \quad 30$

Time ( $\min )$

Fig. 2. Limited proteolytic analysis of the purified acetyl-CoA synthetase. The purified acetyl-CoA synthetase was digested with trypsin, subtilisin $\mathrm{BPN}^{\prime}$ and chymotrypsin at $20^{\circ} \mathrm{C}$ for indicated incubation time and the reaction products were analyzed on a $10 \%$ SDS-polyacrylamide gel. For experimental details, see "Materials and Methods". The positions of the $72 \mathrm{k}$ intact enzyme and the $56 \mathrm{k}$ tryptic fragment are indicated by arrows.

the enzyme using the same procedure as described by Webster (1965), however, the enzyme was not crystallized in our hands. Then, we searched for various conditions including precipitation of the enzyme with ammonium sulfate, polyethylene glycols with various molecular weights and 2-methyl-2,4-pentanediol in the presence or absence of $\mathrm{CoA}$ and/or ADP. We obtained microcrystals when a droplet containing $6 \mathrm{mg}$ protein/ml of the purified enzyme in $50 \mathrm{mM}$ Tris- $\mathrm{HCl}$ ( $\mathrm{pH}$ 8.0), $1 \mathrm{mM}$ DTT, $2 \mathrm{mM} \mathrm{CoA}$ and $4 \mathrm{mM}$ ADP was vapor-diffused at $20^{\circ} \mathrm{C}$ with a solution containing $100 \mathrm{mM}$ Tris-HCl, $\mathrm{pH} 8.0$ and $10 \%(\mathrm{v} / \mathrm{v})$ 2-methyl-2,4pentanediol (Fig. 4). However, these crystals were not suitable for $\mathrm{x}$-ray diffraction study.

Tissue distribution of the enzyme. Tissue distribution of the enzyme was 


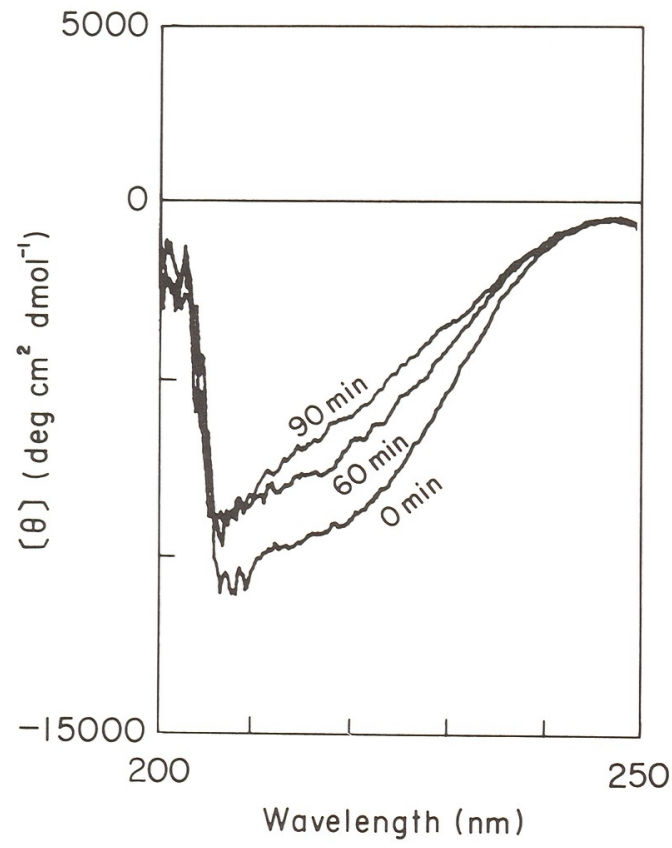

Fig. 3. CD spectral variations of the purified $72 \mathrm{k}$ acetyl-CoA synthetase and the $56 \mathrm{k}$ tryptic fragment. For experimental details, see "Materials and Methods". The trypsin digestion was stopped at the reaction time in the figure.

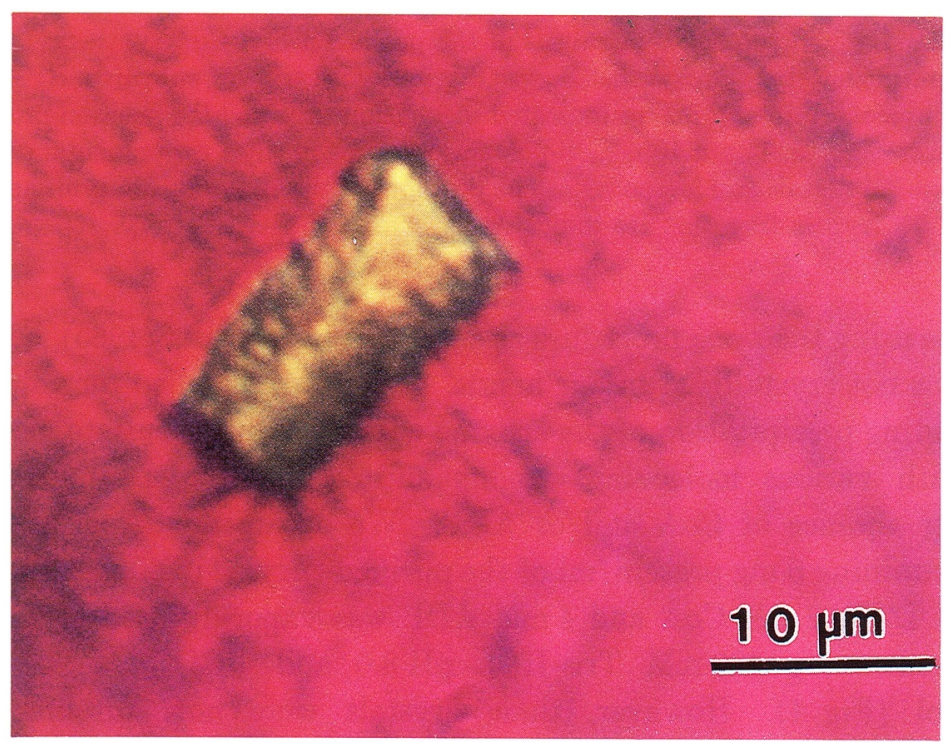

Fig. 4. Crystalline acetyl-CoA synthetase from bovine heart. The photograph was taken under a polarized microscope. 


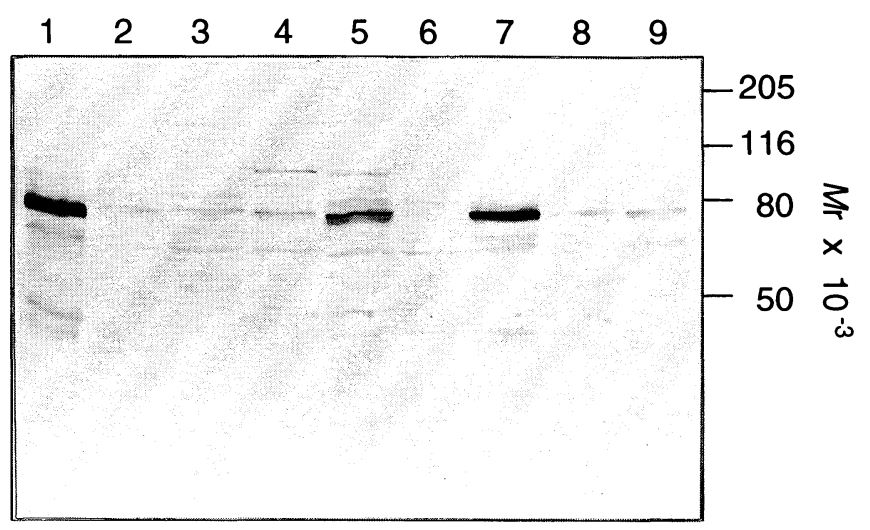

Fig. 5. Western blot analysis of the purified acetyl-CoA synthetase and rat tissues homogenates. One microgram of the purified acetyl-CoA synthetase (lane 1) and $20 \mu \mathrm{g}$ of rat tissue homogenates from muscle (lane 2), adipose tissue (lane 3 ), small intestine (lane 4), kidney (lane 5), liver (lane 6), heart (lane 7), lung (lane 8) and brain (lane 9) were separated on a 10\% SDS-polyacrylamide gel and analyzed by antibodies against bovine acetyl-CoA synthetase. For experimental details, see "Materials and Methods".

analyzed using antibodies against the purified enzyme. The Western blot analysis of the purified enzyme and rat tissue samples detected the $72 \mathrm{k}$ purified enzyme and the same molecular weight protein in rat tissues (Fig. 5). This $72 \mathrm{k}$ protein was most abundant in rat heart and was not detected by control antibodies, suggesting that the cross-reacting protein is the rat homologue of acetyl-CoA synthetase. The $72 \mathrm{k}$ cross-reacting protein was also detected in kidney and, to a much lesser extent in muscle, adipose tissue, lung and brain. This pattern of tissue distribution well agrees with those of mitochondrial acetyl-CoA synthetase activities in rat tissues (Scholte and Groot 1975), indicating that the $72 \mathrm{k}$ protein is a rat homologue of mitochondrial acetyl-CoA synthetase. Consistent with the absence of acetyl-CoA synthetase activity in rat liver mitochondria (Scholte and Groot 1975), we could not detect the protein in liver.

In this study, we have highly purified acetyl-CoA synthetase from bovine heart and characterized it. Although we have succeeded in the crystallization of the enzyme, the obtained crystals were not suitable for the $\mathrm{x}$-ray diffraction studies. Thus, we are currently isolating cDNAs encoding this enzyme. Isolation of a full-length cDNA for acetyl-CoA synthetase and subsequent expression of the enzyme in Escherichia coli will promote studies on the structure and function relationship of this enzyme.

\section{Acknowledgments}

We thank Ms. F. Kim, Ms. C. Katsuda-Nakai and Dr. S. Kanaya for their help in amino acid analysis. We acknowledge Drs. H. Toh and K. Nishikawa for their helpful discussion 
and comments.

\section{References}

1) Abe, T., Fujino, T., Fukuyama, R., Minoshima, S., Shimizu, N., Toh, H., Suzuki, H. \& Yamamoto, T. (1992) Human long-chain acyl-CoA synthetase: Structure and chromosomal location. J. Biochem., 111, 123-128.

2) Bradford, M.M. (1976) A rapid and sensitive method for the quantitation of microgram quantities of protein utilizing the principle of protein-dye binding. Anal. Biochem., 72, 248-254.

3) Connerton, I.F., Fincham, J.R.S., Sandeman, R.A. \& Hynes, M.J. (1990) Comparison and cross-species expression of the acetyl-CoA synthetase genes of the ascomycete fungi, Aspergillus nidulans and Neurospora crassa. Mol. Microbiol., 4, 451-460.

4) De Wet, J.R., Wood, K.V., DeLuca, M., Helinski, D.R. \& Subramani, S. (1987) Firefly luciferase gene: Structure and expression in mammalian cells. Mol. Cell. Biol., 7, 725-737.

5) Díez, B., Gutiérez, S., Barredo J.L., van Solingen, P., van der Voort, L.H.M. \& Martín, J.F. (1990) The cluster of penicillin biosynthetic genes. J. Biol. Chem., 265, 1635816365.

6) Fujino, T. \& Yamamoto, T. (1992) Cloning and functional expression of a novel long-chain acyl-CoA synthetase expressed in brain. J. Biochem., 111, 197-203.

7) Hele, P. (1954) The acetate activating enzyme of beef heart. J. Biol. Chem., 206, 671-676.

8) Hori, K., Yamamoto, Y., Minetoki, T., Kurotsu, T., Kanda, M., Miura, S., Okamura, K., Furuyama, J. \& Saito, Y. (1989) Molecular cloning and nucleotide sequence of the gramicidin S synthetase 1 gene. J. Biochem., 106, 639-645.

9) Kräzschmar, J., Krause, M. \& Marahiel, M.A. (1989) Gramicidin S biosynthesis operon containing the structural genes grsA and grsB has an open reading frame encoding a protein homologous to fatty acid thioesterases. J. Bacteriol., 171, 54225429.

10) Laemmli, U.K. (1970) Cleavage of structural proteins during the assembly of the head of bacteriophage T4. Nature, 227, 680-685.

11) Londesborough, J.C., Yuan, S.L. \& Webster, L.T., Jr. (1973) The molecular weight and thiol residues of acetyl-coenzyme A synthetase from ox heart mitochondria. Biochem. J., 133, 23-36.

12) Lozoya, E., Hoffmann, H., Douglas, C., Schulz, W., Scheel, D. \& Hahlbrock, K. (1988) Primary structures and catalytic properties of isoenzymes encoded by the two 4coumarate: CoA ligase genes in parsley. Eur. J. Biochem., 176, 661-667.

13) Masuda, T., Tastumi, H. \& Nakano, E. (1989) Cloning and sequence analysis of cDNA for luciferase of a Japanese firefly, Luciola cruciata. Gene,. 77, 265-270.

14) Ollis, D. \& White, S. (1990) Protein crystallization. In: Methods in Enzymology, edited by M.P. Deutscher, Vol. 182, Academic Press, San Diego, pp. 646-659.

15) Pearson, D.J. (1965) A source of error in the assay of acetyl-coenzyme A. Biochem. J., 95, 23C-24C.

16) Sambrook, J., Fritsch, E.F. \& Maniatis, T. (1989) Detection and analysis of proteins expressed from cloned genes. In: Molecular Cloning. A Laboratory Manual, edited by II. Cold Spring Harbor Laboratory Press, Cold Spring Harbor, NY, pp. 18601875.

17) Scholte, H.R. \& Groot, P.H.E. (1975) Organ and intracellular localization of shortchain acyl-CoA synthetases in rat and guinea pig. Biochim. Biophys. Acta, 409, 283296.

18) Smith D.J., Earl, A.J. \& Turner, G. (1990) The multifunctional peptide synthetase performing the first step of penicillin biosynthesis in Penicillium chrysogenum is a 421 
073 dalton protein similar to Bacillus brevis peptide antibiotic synthetases. EMBO $J ., 9,2743-2750$.

19) Spackman, D.H., Stein, W.H. \& Moore, S. (1958) Automatic recording apparatus for use in the chromatography of amino acids. Anal. Chem., 30,1190-1206.

20) Suzuki, H., Kawarabayasi, Y., Kondo, J., Abe, T., Nishikawa, K., Kimura, S., Hashimoto, T. \& Yamamoto, T. (1990) Structure and regulation of rat long-chain acyl-CoA synthetase. J. Biol. Chem., 265, 8681-8685.

21) Toh, H. (1990) N-Terminal halves of gramicidin S synthetase 1, and tyrocidine synthetase 1 as novel members of firefly luciferase family. Protein Seq. Data Anal., 3, 517-521.

22) Toh, H. (1991) Sequence analysis of firefly luciferase family reveals a conservative sequence motif. Protein Seq. Data Anal., 4, 111-117.

23) Webster, L.T., Jr. (1965) Studies of the acetyl coenzyme A synthetase reaction. $J$. Biol. Chem., 240, 4158-4169.

24) Weckermann, R., Fübaß, R. \& Marahiel, M.A. (1988) Complete nucleotide sequence of the tycA gene coding the tyrocidine synthetase 1 from Bacillus brevis. Nucl. Acids Res., 16, 11841.

25) Wood, K.V., Lam, Y.A., Seliger, H.H. \& McElroy, W.D. (1989) Complementary DNA coding click beetle luciferases can elicit bioluminescence of different colors. Science, 244, 700-702.

26) Zhao, Y., Kung, S.D. \& Dube, S.K. (1990) Nucleotide sequence of rice 4-coumarate: CoA ligase gene, 4-CL. 1. Nucl. Acid Res., 18, 6144. 